\title{
Analisis Penyebab Cacat Produk Santan Kemasan dalam Penetapan Critical Control Point dengan Pendekatan HACCP di PT. X
}

\author{
Gustiarini Rika Putri ${ }^{1}$, Maria Isfus Senjawati ${ }^{1}$, Yovi Erlinanto ${ }^{1}$ \\ ${ }^{1}$ Program Studi Teknik Industri Agro, Politeknik ATI Padang Jl. Bungo Pasang, Padang, 25171, Indonesia
}

\section{ARTICLE INFORMATION}

Received: December 08, 2020

Revised: December 22, 2020

Available online: December 31, 2020

\section{KEYWORDS}

Bloating, Coconut Milk, Defects, HACCP

\section{CORRESPONDENCE}

Name: Maria Isfus Senjawati

E-mail: mariaisfus@poltekatipdg.ac.id

\section{A B $\mathbf{S}$ T $\mathbf{R}$ A $\mathbf{C}$ T}

Hazard Analysis Critical Control Point (HACCP) ia a quality control system from the preparation of raw maerials to the product and accepted by consumers. HACCP is a requirement for guaranteeing the safety of food products produced according to company quality standards. PT. X produces packaged coconut milk as one of the main products and has implemented HACCP in every production process of its products. The packaged coconut milk that is produced often gets bloated in the finished product warehouse before the product is distributed. Therefore it is necessary to analyze the application of HACCP in the production of packaged coconut milk. HACCP application in the packaged coconut milk production process has set 4 Critical control points. CCP 1 (UHT Sterilization System \& Aseptic Tank), CCP 2 (Filtration 500 micron), CCP 3 (Product Sterilization at $140-148^{\circ} \mathrm{C}$ ) and CCP 4 (Filling with Astepo Filler Filling Machine). Each Critical Control Point has physical and biological hazards, which must be controlled to ensure food safety. The research objective was to analyze the implementation of HACCP plan for coconut milk products based on SNI No. 01-4852-1998 regarding the HACCP system and analyzing the causes of product defects (bloating) in the determination of the CCP. Based on the analysis of HACCP application and the causes of product defects in packaged coconut milk, product defects due to bloating are not defects in the production process but defects caused by cross-contamination of microbes after filling. Cross contamination occurs due to cracks in the neck of the aseptic bag cup that cannot be detected directly, and the use of tools that should not be used during the filling process.

\section{PENDAHULUAN}

Konsumen yang semakin banyak keinginan terhadap fungsi yang dapat diberikan oleh suatu produk, juga menuntut persaingan ketat antar perusahaan, termasuk perusahaan pangan. Perusahaan harus meningkatkan produk yang dihasilkan dengan memberikan keunggulan pada produk, meningkatkan kualitas produk dan memiliki standar kualitas keamanan pangan. Kualitas produk yang dihasilkan harus dipertahankan dan ditingkatkan agar keinginan pelanggan dapat terpenuhi dengan baik setelah menggunakan produk. Salah satu indikator tidak terjaminnya keamanan pangan adalah ditemukan cacat produk yang melebihi batas toleransi perusahaan atau standar yang ditetapkan perusahaan.

Kecacatan produk juga merupakan masalah serius bagi perusahaan karena setiap kecacatan yang terjadi akan menimbulkan biaya tambahan bagi perusahaan, Oleh karena itu, pengoptimalan proses produksi diperlukan pengendalian kualitas agar dapat meminimalkan kerusakan kerusakan yang terjadi tanpa menimbulkan biaya produksi yang besar bagi perusahaan sehingga perusahaan dapat memproduksi dengan kualitas yang baik dan dengan biaya minimal yang sesuai dengan kebutuhan konsumen.

Selain pengendalian kualitas, keamanan pangan merupakan faktor penting yang harus dijaga oleh perusahaan agar produk aman saat dikosumsi oleh pelanggan maupun perusahaan yang akan menggunakan sebagai bahan baku untuk produk mereka. Salah satunya dengan cara tidak mentolerir satupun produk cacat yang dihasilkan, karena diasumsikan produk cacat dihasilkan dari proses yang tidak sesuai standar. Perusahaan dituntut untuk mampu mengikuti standar keamanan pangan yang telah ditetapkan dalam ISO 22000 maupun PP no 86 tahun 2019 tentang keamanan pangan. 
Salah satu penerapan keamanan pangan yang harus diaplikasikan oleh industri pangan adalah Hazard Analysis Critical Control Point (HACCP). Menurut [1] HACCP merupakan salah satu implementasi standar keamanan pangan yang harus dilaksanakan oleh industri pangan untuk menjamin produk yang dihasilkan aman bagi konsumen. Pengendalian mutu dilakukan mulai dari bahan baku dipersiapkan sampai produk akhir diproduksi masal dan diterima konsumen. HACCP menjadi syarat jaminan keamanan pangan yang dihasilkan sudah memenuhi standar mutu perusahaan.

Melalui pendekatan HACCP dengan tujuh prinsipnya, penentuan titik kritis atau critical control pointmenjadi salah satu prinsip HACCP. Menurut [2] critical control point merupakan setiap titik, tahap atau prosedur pada suatu sistem produksi makanan yang dapat mengendalikan faktor bahaya biologi atau mikrobiologi, kimia atau fisika. Oleh karena itu, adanya produk santan kelapa yang merupakan produk jadi (finish good) masih ditemukan produk bloating (kembung) saat disimpan di gudang finish good. Penemuan produk bloating ini memang tidak terjadi setiap hari, namun permasalahan produk bloating ini menjadi permasalahan yang cukup serius yang dialami perusahaan, terlebih jika produk mengalami bloating sudah berada di tangan konsumen.

Berdasarkan data bloating produk santan kemasan selama bulan Januari 2020, terdapat 6 kasus produk bloating. Kasus ini juga ditemukan pada bulan Februari 2020, yaitu sebanyak 5 kasus dan pada bulan Maret 2020, ditemukan kembali 6 kasus bloating. Dengan mengacu pada standar mutu pengendalian kualitas perusahaan, tidak diperbolehkan adanya kasus bloating (zero bloating) dan produk bloating tidak dibolehkan sampai diterima konsumen. Jika dianalisis dari penetapan CCP santan kemasan, maka perlu ditinjau kembali setiap CCP yang telah ditetapkan kemungkinan akan memberikan penyebab cacat produk santan kemasan.

\section{METODOLOGI}

Penelitian dilakukan pada area proses produksi coconut milk dan laboraturium quality control departemen liquid PT. X bersama tim QC departemen liquid, analisis dilakukan berpedoman dengan paduan penyusunan Rencana HACCP [3] dimana dilakukan Analisis bahaya dengan cara mendaftarkan semua bahaya yang mungkin terdapat dalam bahan baku dan tahap proses. Bahayabahaya yang teridentifikasi kemudian ditabulasikan ke dalam sebuah tabel disertai sumber bahaya, tingkat resiko dan tindakan pencegahannya. tingkat resiko ditentukan berdasarkan seberapa besar akibat yang akan ditimbulkan oleh suatu bahaya dan seberapa sering bahaya tersebut kemungkinan terjadi.

Setiap bahan baku dan tahap proses ditentukan termasuk $\mathrm{CCP}$ atau tidak melalui pertimbangan tingkat resiko dan berdasarkan jawaban atas pertanyaan dari CCP decision tree. Bahan baku dan tahap proses yang termasuk CCP berarti harus dikendalikan dengan baik supaya tidak berbahaya bagi kesehatan manusia. Tahap proses yang tidak termasuk CCP, dapat termasuk control point (CP) yang berarti tahapan tersebut apabila tidak dikendalikan dengan baik dapat menyebabkan kecacatan dari segi kualitas.

Tahapan yang ditetapkan sebagai CCP dilakukan tindakan monitoring agar proses tetap berada dalam standar yang ditetapkan. Kemudian juga ditetapkan tindakan perbaikan pada tahapan yang ditetapkan sebagai CCP dan semua tindakan perbaikan harus tercatat dalam dokumen perusahaan.

Prinsip sistem HACCP yang direkomendasikan oleh Badan Standar Nasional Indonesia melalui [4] yang meliputi:

1. Prinsip 1: Analisis bahaya dan pencegahannya

2. Prinsip 2: Identifikasi Critical control points (CCP) di dalam proses

3. Prinsip 3: Menetapkan batas kritis untuk setiap CCP

4. Prinsip 4: Menetapkan cara pemantauan CCP

5. Prinsip 5: Menetapkan tindakan koreksi

6. Prinsip 6: Menyusun prosedur verifikasi

7. Prinsip 7: Menetapkan prosedur pencatatan (dokumentasi)

Pada penelitian ini akan dianalisis kembali CCP yang telah ditetapkan melalui identifikasi bahaya yang harus dikendalikan, tindakan pengendalian dan Critical Limit.

\section{Teknik Pengumpulan Data}

1. Wawancara yaitu dengan melakukan tanya jawab secara langsung dengan pihak yang bertanggung jawab pada bagian quality control dan operator yang terlibat secara langsung dalam proses produksi.

2. Observasi yaitu dengan melakukan pengamatan secara langsung pada proses produksi coconut milk di departmen liquid PT. X

\section{HASIL DAN PEMBAHASAN}

\section{Data Cacat Produk Kembung (Bloating)}

Adapun data cacat kembung (bloating) produk santan kemasan yang diproduksi oleh PT. X pada bulan Januari sampai dengan bulan Maret tahun 2020 dapat dilihat pada Tabel 1. 
Tabel 1. Data Cacat Kembung (Bloating) Produk Santan Kemasan

\begin{tabular}{|c|c|c|c|c|c|}
\hline No & Nama Produk & Jumlah & Tanggal Produksi & Tanggal Reject & No Box \\
\hline \multicolumn{6}{|c|}{ Bulan Januari } \\
\hline 1 & Coconut Milk FC 24 @20L & 1 & 25 Des 19 & 05 Jan 20 & 132 \\
\hline 2 & Coconut Milk FC 24 @20L & 1 & 01 Jan 20 & 09 Jan 20 & 143 \\
\hline 3 & Coconut Milk FC 20 @20L & 1 & 07 Jan 20 & 12 Jan 20 & 261 \\
\hline 4 & Coconut Cream FC 24 @20L & 1 & 18 Jan 20 & 23 Jan 20 & 213 \\
\hline 5 & Coconut Cream FC $24 @ 20 L$ & 1 & 19 Jan 20 & 25 Jan 20 & 122 \\
\hline 6 & Coconut Cream FC 24 @20L & 1 & 24 Jan 20 & 27 Jan 20 & 172 \\
\hline \multicolumn{2}{|r|}{ Jumlah } & 6 & & & \\
\hline \multicolumn{6}{|c|}{ Bulan Februari } \\
\hline 1 & Coconut Milk FC 24 @20L & 1 & $25 \operatorname{Jan} 20$ & 02 Feb 20 & 226 \\
\hline 2 & Coconut Milk FC 24 @20L & 1 & 02 Feb 20 & $11 \mathrm{Feb} 20$ & 125 \\
\hline 3 & Coconut Milk FC 20 @20L & 2 & 05 Feb 20 & 14 Feb 20 & 231 \\
\hline \multirow[t]{2}{*}{4} & Coconut Cream FC $24 @ 20 L$ & 1 & 17 Feb 20 & 23 Feb 20 & 72 \\
\hline & Jumlah & 5 & & & \\
\hline \multicolumn{6}{|c|}{ Bulan Maret } \\
\hline 1 & Coconut Cream FC 24 @20L & 1 & $19 \mathrm{Feb} 20$ & $26 \mathrm{Feb} 20$ & 115 \\
\hline 2 & Coconut Cream FC 24 @20L & 1 & 28 Feb 20 & 5 Mar 20 & 334 \\
\hline 3 & Coconut Cream FC 24 @20L & 1 & 3 Mar 20 & $10 \operatorname{Mar} 20$ & 261 \\
\hline 4 & Coconut Cream FC 24 @20L & 1 & $12 \operatorname{Mar} 20$ & $16 \operatorname{Mar} 20$ & 47 \\
\hline 5 & Coconut Milk FC 17 @20L & 1 & 25 Feb 20 & $16 \operatorname{Mar} 20$ & 663 \\
\hline 6 & Coconut Cream FC 24 @20L & 1 & $23 \operatorname{Mar} 20$ & 30 Mar 20 & 57 \\
\hline \multirow[t]{2}{*}{7} & Coconut Cream FC 24 @20L & 1 & $23 \operatorname{Mar} 20$ & $30 \operatorname{Mar} 20$ & 127 \\
\hline & Jumlah & 7 & & & \\
\hline
\end{tabular}

Sumber: PT. X

Data diatas merupakan data produk santan kemasan yang mengalami bloating yang pada bulan Januari sampai dengan maret tahun 2020, dimana produk yang mengalami bloating ini ditemukan saat produk disimpan di gudang finish good, produk yang mengalami bloating terdapat perbedaan fisik dengan produk yang lainnya, dimana produk yang bloating mengalami perubahan fisik menggembung menyerupai balon seperti Gambar 1 berikut.

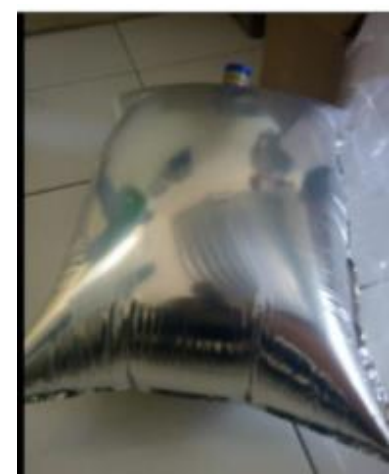

Gambar 1. Santan Kemasan Bloating
Penetapan Critical control pointpada HACCP Plan Produk Coconut milk PT. XYZ

Berdasarkan hasil pengamatan dan analisis di PT. X telah menerapkan sistem keamanan pangan dan HACCP pada produksi coconut milk meliputi 10 langkah penerapan dengan 7 prinsip HACCP. Langkah penerapan HACCP adalah penetapan tim HACCP, deskripsi produk, penentuan diagram alir, identifikasi bahaya, penentuan Critical Control Point (CCP), penetapan batas kritis tiap CCP, monitoring, tindakan koreksi, verifikasi, dan dokumentasi.

Adapun tahapan penentuan CCP dan batas kritis yang merupakan langkah kelima dari tahapan HACCP plan dan prinsip ketiga. 
Tabel 2. Penentuan CCP dan Batas Kritis (Prinsip 3)

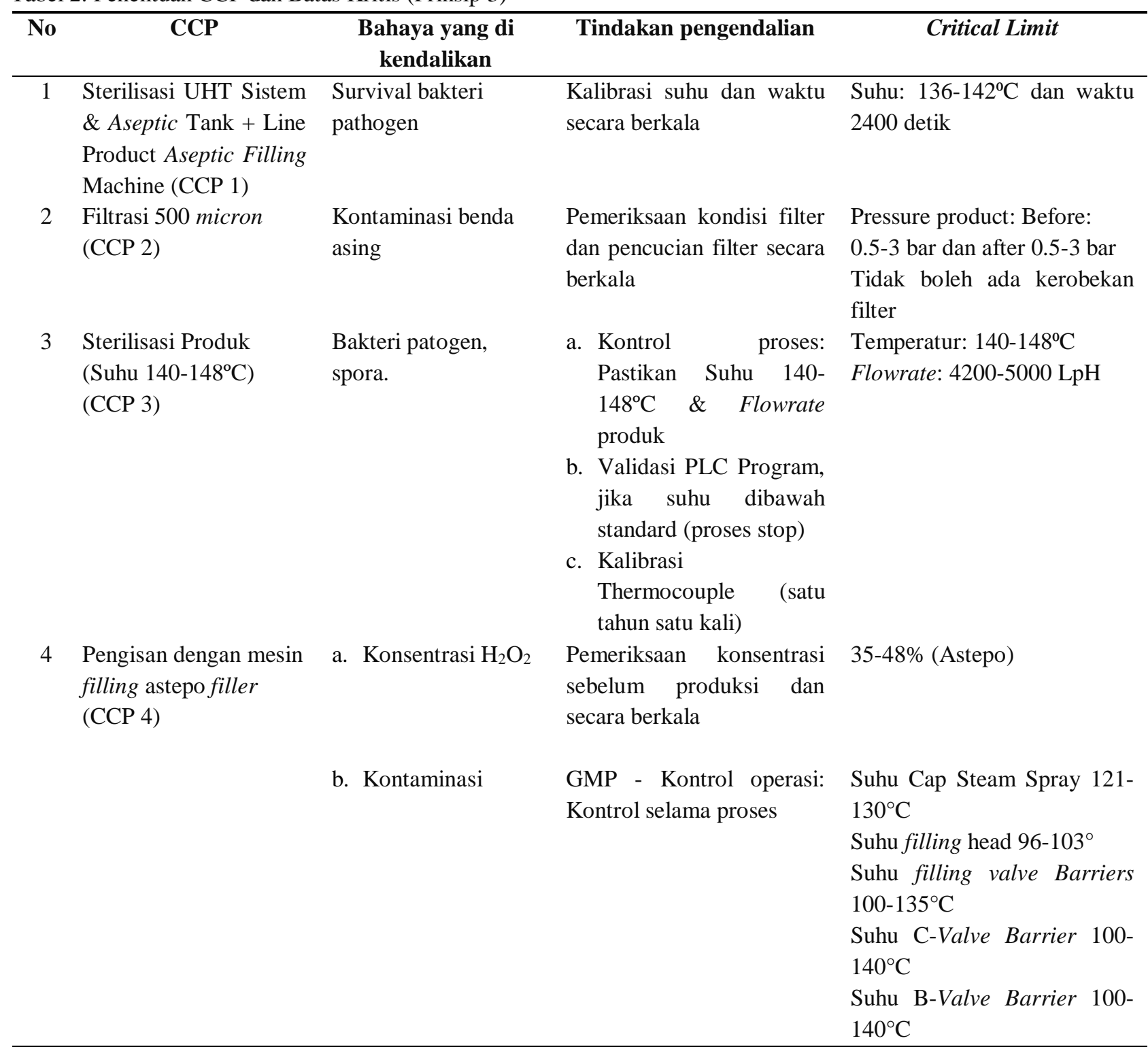

Sumber: HACCP Plan PT. X

\section{Pembahasan}

Berdasarkan dari data laporan produk bloating selama tiga bulan yaitu bulan Januari sampai dengan Maret 2020, dapat dilihat bahwa setiap bulan masih adanya produk yang mengalami bloating, dimana kecacatan produk akibat bloating ini sangat bertentangan dengan kebijakan mutu dan keamanan pangan (quality and food safety policy) perusahaan.

Menurut dokumen standar manajemen mutu dan keamanan pangan, perusahaan memiliki sasaran untuk memproduksi produk yang aman, legal, bermutu dan tanpa unsur penipuan (food fraud) dengan tingkat penerimaan mutu pada 1:10.000 dan menerapkan prinsip bebas cacat dalam jangka panjang, yang mana artinya kecacatan produk akibat bloating memang dikendalikan secara disiplin agar tidak terjadi kasus cacat produk.
Kecacatan produk akibat bloating ini sangat berpengaruh, dimana produk bloating ini menandakan ada sebuah proses yang unsterile (tidak bersih dan bebas dari kontaminasi), sehingga mengakibatkan mikroba berkembang dan merubah konsentrasi $\mathrm{pH}$ santan sehingga produk mengalami bloating [5]. Meskipun kasus bloating ini ditemukan hanya beberapa kasus tiap bulan nya namun ini memberikan pengaruh besar terhadap keamanan pangan produk santan kemasan dan kepercayaan konsumen terhadap produk perusahaan.

\section{Penyebab Produk Coconut milk Bloating}

Dari hasil pengamatan yang dilakukan pada proses produksi santan kemasan dan salah satu produk yang mengalami bloating, bersama tim QC department Liquid PT. X ditemukan beberapa penyebab produk bloating antara lain:

1. Terjadinya kontaminasi silang dengan mikroba after filling, ini ditunjukan dengan di temukan nya 
Salmonella, Klebsiela, Proteus \& pathogen lain, jamur dan lainnya yang mengakibatkan turunya $\mathrm{pH}$ santan dan merusak santan.

2. Ditemukannya keretakan pada leher bagian dalam dari cup aseptic bag kondisi retaknya leher aseptic bag tersebut tidak bisa di deteksi dengan kasat mata terlebih pada saat inspeksi aseptic bag tidak boleh di buka tutup cup nya,retak nya leher aseptic bag ini diketahui setelah kami membuka dan membedah produk yang mengalami bloating dan memeriksa kenapa produk tersebut bisa terkontaminasi mikroba dari luar sehingga menyebabkan produk coconut milk mengalami asam atau PH nya dibawah standar, retaknya leher aseptic bag ini di tandai adanya renggangan di leher cup aseptic bag seperti terlihat pada Gambar berikut ini:

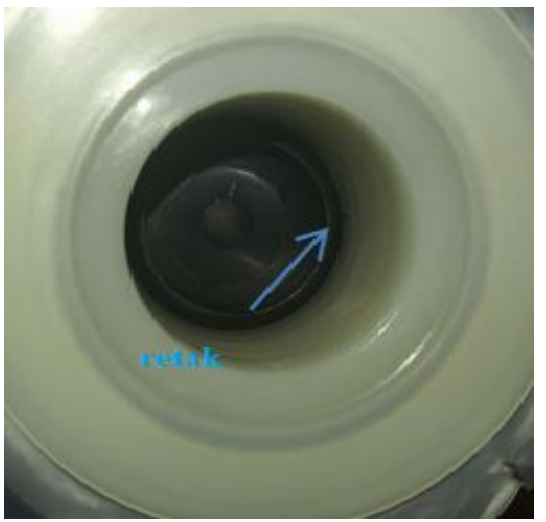

(a)

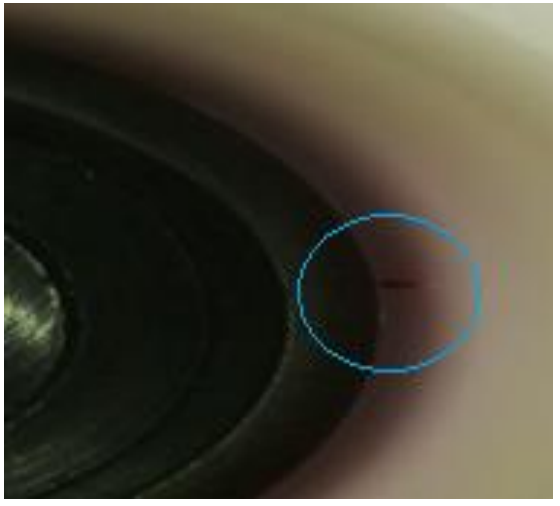

(b)

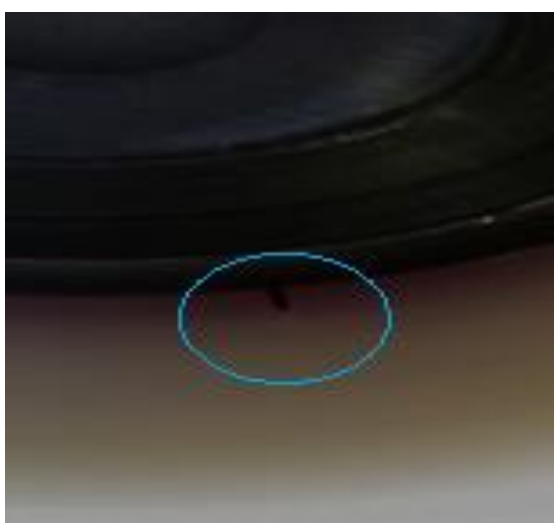

(c)

Gambar 2. (a) (b) (c) Retak pada Leher Cup aseptic bag
Dari gambar 2 dapat dilihat ada retakan kecil yang sulit dilihat tanpa kaca pembesar saat dilakukan pemeriksaan mesin dan peralatan. Selain itu kondisi retakan pada bagian dalam alat packing juga menajdi faktor tidak terdeteksinya kerusakan. Keretakan pada leher cup aseptik bag ini menyebabkan bakteri dan mikroba mengkontaminasi mikroba masuk dan merusak produk santan kemasan pada saar proses packing aseptic sehingga mengalami kembung

Dari penenemuan penyebab cacat produk tersebut sebaiknya ditambahkan tahapan proses yang tergolong kedalam CCP yaitu uji keretakan menggunakan alat pendeteksi keretakan/flow detector dengan batas kritisnya tidak boleh ada keretakan, proses ini dilakukan sebelum proses pengemasan produk dan pengepakan ke dalam karton sehingga kasus produk bloating ini bisa dihindari akibat keretakan leher cup aseptic bag tersebut.

3. Ditemukannya penggunaan alat yang tidak dianjurkan penggunaan nya dalam manual book mesin astepo filler,yaitu penggunaan kanebo yang di lobangi di tengah nya lalu di pasangkan di leher aseptic bag pada saat filing yang fungsinya sebagai pembatas plastik aseptic bag dengan box aseptic Chamber, sebab kanebo ini dalam keadaan yang basah memungkinkan berkumpulnya mikroba sehingga memungkinkan terjadi kontaminasi silang pada saat pengisian,sebab kanebo ini tidak ikut di sterilisasi pada saat mensterilisasi cup aseptic bag terlebih pada saat pengisisan dengan kapasitas 1000 $\mathrm{kg}$ yang membutuhkan waktu yang relatif lama.terlebih dari hal itu penggunaan kanebo ini tidak dianjurkan oleh produsen mesin astepo filler.

\section{Analisis Penetapan CCP dan batas kritis pada HACCP Plan Santan Kemasan}

Prinsip HACCP yang ketiga adalah penentuan CCP (Critical Control Point). Penentuan CCP dapat dilakukan dengan menggunakan pohon keputusan. Batas kritis adalah sebuah titik kendali yang dilakukan untuk menghilangkan bahaya atau menurunkannya hingga batas aman. [1] Batas kritis harus ditetapkan secara spesifik dan divalidasi terlebih dahulu. Kriteria yang sering digunakan sebagai batas kritis adalah hasil pengukuran suhu, waktu, tingkat kelembaban, $\mathrm{pH}, \mathrm{Aw}$, kandungan klorin, tekstur, dan kenampakan visual. [6]

Pada HACCP plan produk coconut milk PT. X terdapat empat proses yang digolongkan kepada proses CCP antara lain:

1. Proses sterilisasi UHT system dan aseptic tank serta sterilsasi line product aseptic filling machine

2. Proses Filtrasi 500 micron 


\section{Poses Sterilisasi Produk (coconut milk)}

4. Proses filling oleh mesin astepo filler

Dimana proses sterilisasi UHT system dan dan aseptic tank serta sterilsasi line product aseptic filling machine ini bertujuan guna mensterilkan peralatan yang akan digunakan agar steril sehinga setelah produk disterilkan tidak mengalami kontaminasi silang dengan mikroba yang dapat menyebabkan rusaknya produk sehingga produk mengalami bloating (kembung) saat sudah dilakukan filling (pengisian). Menurut [2] untuk mensterilkan suatu benda dan peralatan menggunakan uap steam harus dengan suhu dengan minimal $134^{\circ} \mathrm{C}$ dengan tekanan maksimum 2 bar dengan waktu minimal 45 menit untuk memanaskan dan 15 menit untuk proses sterilisasi, berdasarkan pernyataan tersebut secara keseluran proses CCP 1 sudah memenuhi standar yang telah di tentukan menurut para ahli. Pada PT. X proses sterilisasi ini dilakukan $1 \times 24$ jam dimana satu kali proses sterilisasi UHT system dan dan aseptic tank serta sterilsasi line product aseptic filling machine menghabiskan waktu 5 jam untuk proses pemanasan UHT system dan dan aseptic tank serta sterilsasi line product aseptic filling machine dan proses sterilasinya 2400 detik atau 40 menit, sehingga pada proses ini sudah memenuhi standar yang sudah di tetapkan.

Proses yang tergolong proses CCP selanjutnya adalah proses filtrasi dengan ukuran filter 500 micron dengan batas kritis nya tidak boleh ada kerobekan, menurut [2] secara umum proses filtrasi dilakukan bila jumlah padatan (bahaya fisik) dalam suspensi relative lebih kecil di bandingkan zat cairnya. Sehingga proses sterilasi sudah memenuhi standar yang berlaku dimana bahaya fisika suspensi berupa ampas tidak bisa melewati ukuran filter 500 micron.

Menurut Proses selanjutnya yaitu proses Sterilisasi Produk (coconut milk) menggunakan mesin Ultra High Temperature (UHT) dengan suhu $140-148^{\circ} \mathrm{C}$ dengan waktu 8-15 detik, [5] menjelaskan bahwa produksi santan kemasaan dari tetra pak sudah terjamin kualitasnya karena melalui proses UHT dan memakai kemasaan aseptic. Rasa dan nutrisi santan melalui teknologi UHT dan kemasaan aseptic tetap terjaga karena santan dipanaskan dengan suhu $140^{\circ} \mathrm{C}$ dalam waktu 8-15 detik sehingga kondisi sterilitas komersial tercapai.
Berdasarkan penjelasan di atas proses UHT santan kemasan di PT. X sudah dengan suhu minimal $140^{\circ} \mathrm{C}$ dan maksimal $148^{\circ} \mathrm{C}$ dengan waktu 8-15 detik, Proses UHT ini bertujuan membunuh spora, bakteri dan patogen yang tidak tuntas pada saat proses pasteurisasi. Batas kritis yang dikendalikan pada proses ini yaitu mengendalikan suhu UHT dalam range $140-148^{\circ} \mathrm{C}$ serta kecepatan aliran santan (floerate) 5200 liter/jam, berdasarkan SNI No. 01-4852-1998 proses UHT dan penetapan sebagai CCP 3 sudah memenuhi standar yang telah di tentukan.

Proses selanjutnya yang dikategorikan sebagai CCP adalah proses filling menggunakan mesin aseptic filling, dalam proses filing terdapat beberapa batas kritis sebagai berikut:

1. Suhu filling $96-103^{\circ} \mathrm{C}$.

2. Suhu Cap Steam Spray $121-130^{\circ} \mathrm{C}$

3. Suhu Filling valve Barriers $100-135^{\circ} \mathrm{C}$

4. Suhu C-Valve Barrier $100-140^{\circ} \mathrm{C}$

5. Suhu B-Valve Barrier $100-140^{\circ} \mathrm{C}$

6. Konsentrasi $\mathrm{H}_{2} \mathrm{O}_{2}$ Max 35-48\%

Dapat dilihat pada saat proses filling sudah dilaksanakan dengan kedisiplinan yang tinggi terhadap semua prosedur dan standar untuk menghindari dari kontaminasi bahaya, seperti biologi maupun kimia. Hal ini dibuktikan dengan konsentrasi $\mathrm{H}_{2} \mathrm{O}_{2}$ yang digunakan untuk disenfektan peralatan filling dan sterilisasi cup aseptic bag maksimal 35-45\% dan proses filling sudah memenuhi standar.

Setelah dirunut kembali pada tahapan sebelumnya, yaitu penetapan potensi bahaya yang akan mempengaruhi penetapan CCP, maka dapat kita lihat tahapan proses aseptic filling yang merupakan langkah ke sembilan dari tahapan proses atau prinsip pertama dan kedua. Maka bahaya biologi dengan jenis bahaya rekontaminasi bakteri yang akan disebabkan oleh peralatan dan setting parameter proses tidak sesuai merupakan CCP, seperti yang dapat kita lihat pada Tabel 3.

Berdasarkan identifikasi penyebab produk botling pada santan kemasan, maka dapat ditetapkan bahaya biologi pada CCP ke 4 merupakan CCP sehingga batas kritis juga ditetapkan pada CCP seperti Tabel 4. 
Tabel 3. Jenis Bahaya, Penyebab Bahaya, Cara Pengendalian dan Penetapan CCP pada Proses Aseptic Filling Machine

\begin{tabular}{|c|c|c|c|c|c|c|}
\hline Langkah & Proses & Bahaya & $\begin{array}{l}\text { Jenis Bahaya } \\
\text { (Prinsip 1) }\end{array}$ & Penyebab & $\begin{array}{l}\text { Cara pengendalian } \\
\text { (Prinsip 2) }\end{array}$ & $\mathrm{CCP} / \mathrm{CP}$ \\
\hline \multirow{4}{*}{9,4} & \multirow{4}{*}{$\begin{array}{l}\text { Aseptic } \\
\text { Filling } \\
\text { Machine } \\
\text { (CCP 4) }\end{array}$} & $\mathrm{K}$ & $\begin{array}{l}\text { Kelebihan residual } \\
\mathrm{H}_{2} \mathrm{O}_{2}\end{array}$ & $\begin{array}{l}\text { Residual } \mathrm{H}_{2} \mathrm{O}_{2} \\
\text { lebih dari } \\
\text { standard } \\
\text { Konsentrasi } \mathrm{H}_{2} \mathrm{O}_{2} \\
\text { tidak sesuai } \\
\text { standard }\end{array}$ & $\begin{array}{l}\text { Pemeriksaan residu } \mathrm{H}_{2} \mathrm{O}_{2} \\
\text { secara berkala } \\
\text { Pemeriksaan konsentrasi } \\
\text { sebelum produksi dan secara } \\
\text { berkala }\end{array}$ & $\mathrm{CCP}$ \\
\hline & & B & $\begin{array}{l}\text { Rekontaminasi } \\
\text { bakteri }\end{array}$ & $\begin{array}{l}\text { Peralatan \& setting } \\
\text { parameter proses } \\
\text { tidak sesuai }\end{array}$ & $\begin{array}{l}\text { Kontrol selama proses CIP } \\
\text { dan sterilisasi peralatan dan } \\
\text { setting parameter proses sesuai } \\
\text { SOP, khusus untuk intasept } \\
\text { bag sterilisasi kemasan sudah } \\
\text { dilakukan dari manufacturing/ } \\
\text { supplier dengan melihat } \\
\text { adanya indikator pada label } \\
\text { carton box. }\end{array}$ & $\mathrm{CP}$ \\
\hline & & $\mathrm{F}$ & Tidak teridentifikasi & & & - \\
\hline & & A & Tidak teridentifikasi & & & - \\
\hline
\end{tabular}

Tabel 4. Perbaikan Penetapan CCP 4 (Pengisan dengan Mesin Filling Astepo Filler) pada Bahaya Kontaminasi Bakteri

\begin{tabular}{|c|c|c|c|}
\hline CCP (ke 4) & Bahaya yang dikendalikan & Tindakan pengendalian & Critical limit \\
\hline \multirow{10}{*}{$\begin{array}{l}\text { Pengisan dengan mesin } \\
\text { filling astepo filler } \\
(\mathrm{CCP} 4)\end{array}$} & Konsentrasi $\mathrm{H}_{2} \mathrm{O}_{2}$ & $\begin{array}{l}\text { Pemeriksaan konsentrasi } \\
\text { sebelum produksi dan } \\
\text { secara berkala }\end{array}$ & 35-48\% (Astepo) \\
\hline & \multirow{4}{*}{ Kontaminasi bakteri } & \multirow{4}{*}{$\begin{array}{l}\text { GMP - Kontrol operasi: } \\
\text { Kontrol selama proses }\end{array}$} & $\begin{array}{l}\text { Suhu Cap Steam Spray 121- } \\
130^{\circ} \mathrm{C} \\
\text { Suhu Filling head } 96-103^{\circ} \mathrm{C}\end{array}$ \\
\hline & & & $\begin{array}{l}\text { Suhu Filling valve Barrier } \\
100-135^{\circ} \mathrm{C}\end{array}$ \\
\hline & & & $\begin{array}{l}\text { Suhu C-Valve Barrier 100- } \\
140^{\circ} \mathrm{C}\end{array}$ \\
\hline & & & $\begin{array}{l}\text { Suhu B-Valve Barrier 100- } \\
140^{\circ} \mathrm{C}\end{array}$ \\
\hline & & \multirow{5}{*}{$\begin{array}{l}\text { Kontrol selama proses } \\
\text { CIP dan sterilisasi } \\
\text { peralatan dan setting } \\
\text { parameter proses sesuai } \\
\text { SOP }\end{array}$} & $\begin{array}{l}\text { Tidak ada kebocoran pada } \\
\text { Flexible hose }\end{array}$ \\
\hline & & & $\begin{array}{l}\text { Tidak ada kebocoran pada } \\
\text { Pipe Joint }\end{array}$ \\
\hline & & & $\begin{array}{l}\text { Tidak ada kebocoran pada } \\
\text { shaft filling pipe }\end{array}$ \\
\hline & & & Tidak ada keretakan pada \\
\hline & & & \\
\hline
\end{tabular}

\section{KESIMPULAN}

Secara keseluruhan HACCP plan proses produksi santan kemasan sudah memenuhi SNI No. 01-48521998, penerapan Good Manufacturing Practice (GMP) dan Sanitation Standard Operation Prosedur (SSOP) di area produksi liquid sudah terlaksana dengan baik. Kecacatan produk akibat bloating bukan merupakan kecacatan pada proses proses, akan tetapi kecacatan yang di akibatkan kontaminasi silang mikroba after filling. Mikroba yang menyebabkan coconut milk bloating yang paling umum terdektesi adalah Salmonella, Klebsiela, Proteus \& patogen lain, jamur dan lainnya yang mengakibatkan turunya $\mathrm{pH}$ santan dan merusak santan. Kontaminasi silang mikroba setelah proses filling disebabkan adanya retakan di leher cup aseptic bag yang tidak dapat di deteksi secara lansung, serta penggunaan alat yang tidak seharusnya di gunakan pada saat proses filling. 
Menambahkan suatu proses inspeksi yang digolongkan kedalam proses CCP yaitu uji keretakan menggunakan alat pendeteksi keretakan/flow detector dengan batas kritisnya tidak boleh ada keretakan, proses ini dilakukan sebelum proses pengemasan produk dan pengepakan ke dalam karton sehingga kasus produk bloating ini bisa dihindari akibat keretakan leher cup aseptic bag tersebut.

Berdasarkan dari kesimpulan diatas, penulis menyarankan beberapa hal perbaikan diantara lain melakukan penelitian lanjutan tentang penerapan HACCP pada proses produksi santan kemasan dengan mengaplikasikan penggunaan alat pengecek keretakan (flow detector) sebelum proses pengemasan dan pengepakan produk kedalam karton, dengan control point nya tidak boleh ada keretakan.

\section{DAFTAR PUSTAKA}

[1] Taheer, H. "Sistem Manajemen HACCP". Jakarta: Bumi Aksara. 2005.

[2] Rauf, R. "Sanitasi Pangan \& HACCP". Yogyakarta: Graha Ilmu. 2013.

[3] BSN. "Sistem Analisa Bahaya dan Titik Kendali Kritis". Departemen Perindustrian Indonesia SNI 01-4852-1998. 1998.

[4] BSN. "Pedoman Penyusunan Rencana Sistem Analisa Pengendalian Bahaya dan Titik Kendali Kritis (HACCP)". BSN.Pedoman 1004-1999. 1999.

[5] Surono, Ingrid. S, Agus Sudibyo, dan Priyo Waspodo. "Pengantar Keamanan Pangan Untuk Industri Pangan”. Yogyakarta: Deepublish. 2016.

[6] Mardesci, Hermiza. "Studi Penerapan HACCP pada Proses Pengolahan Santan Kaleng (Canned Coconut milk) (Studi Kasus pada PT. RSUP-Ind Pulau Burung. Indragiri Hilir)”. Jurnal Teknologi Pertanian, vol. 1, no. 1, pp. 60-76, 2012. 